\title{
Moderate and severe symptoms of anxiety and depression are increased among female medical students during the COVID-19 pandemic
}

\author{
Sintomas moderados e severos de ansiedade e depressão estão aumentados entre estudantes de \\ medicina do sexo feminino durante a pandemia pelo COVID-19
}

Los síntomas moderados y severos de ansiedad y depresión aumentan entre las estudiantes de medicina durante la pandemia por COVID-19

Received: 04/23/2021 | Reviewed: 05/12/2021 | Accept: 05/15/2021 | Published: 06/01/2021

Carlos Izaias Sartorão Filho

ORCID: https://orcid.org/0000-0003-4710-3392 Educational Foundation of the Municipality of Assis, Brazil University of São Paulo State, Brazil

E-mail: carlos.sartorao@unesp.br

Wilson Conte de Las Villas Rodrigues

ORCID: https://orcid.org/0000-0001-7061-943X Educational Foundation of the Municipality of Assis, Brazil E-mail: wilson@femanet.com.br

Ricardo Beauchamp de Castro

ORCID: https://orcid.org/0000-0002-3794-0501 Educational Foundation of the Municipality of Assis, Brazil

E-mail: clinicabeauchamp@gmail.com

Arlete Aparecida Marçal

ORCID: https://orcid.org/0000-0001-8290-9135 Educational Foundation of the Municipality of Assis, Brazil E-mail: aapmarcal@yahoo.com.br

Shirlene Pavelqueires

ORCID: https://orcid.org/0000-0002-8740-351X Educational Foundation of the Municipality of Assis, Brazil E-mail: shirlene@famema.br

Luiz Takano

ORCID: https://orcid.org/0000-0002-8228-9295 Educational Foundation of the Municipality of Assis, Brazil University of São Paulo State, Brazil E-mail: takano.luiz@gmail.com

Wilson Luis de Oliveira

ORCID: https://orcid.org/0000-0001-9099-3875 Educational Foundation of the Municipality of Assis, Brazil E-mail: eurocisf@gmail.com

Carlos Izaias Sartorão Neto

ORCID: https://orcid.org/0000-0003-4057-1732 University of São Paulo, Brazil E-mail: neto.sartorao@usp.br

\begin{abstract}
Background: Emotional disorders in medical students are expected and deserve more attention, especially during the COVID-19 Pandemic. Objective: Evaluate anxiety and depression disorders among medical students during the COVID-19 Pandemic. Methods: A cross-sectional study at a private medical college in Brazil, two months after stayat-home order and postponed classes due to the COVID-19 Pandemic. A survey among medical students was conducted in May 2020, using questionnaires regarding social and demographic status, the GAD-7 for symptoms of anxiety, and the PHQ-9 for symptoms of depression. Results: A total of 340 of 347 (97.98\%) medical students participated. The average GAD-7 score was $9.18( \pm 4.75)$, and the average PHQ-9 score was $12.72( \pm 6.62)$. The results indicate a significant positive relationship between GAD-7 and females $(\mathrm{F}=5.816 P=.016)$. Using a cut-off score of 10 for $\mathrm{GAD}$ 7, $157(46.17 \%)$ students were identified with moderate or severe anxiety symptoms. For the PHQ-9 score, using a cutoff of 10219 (64.41\%), students were recognized with moderate or severe symptoms of depression; the results indicate a significant positive relationship between the PHQ-9 and females ( $\mathrm{F}=5.640 \mathrm{P}=.018$ ). Conclusion: The analysis demonstrated a significantly higher prevalence of moderate and severe anxiety and depression symptoms among female medical students during the COVID-19 Pandemic.
\end{abstract}

Keywords: COVID-19; Mental Health; Student, Medical; Anxiety; Depression. 


\begin{abstract}
Resumo
Histórico: Os transtornos emocionais em estudantes de medicina são frequentes e merecem atenção especial durante a Pandemia pelo COVID-19. Objetivo: Avaliar sintomas de transtornos de ansiedade e depressão entre estudantes de medicina durante a Pandemia COVID-19. Métodos: Estudo transversal em uma faculdade particular de medicina no Brasil, dois meses após a ordem de permanência em casa e aulas online devido à Pandemia pelo COVID-19. A pesquisa entre estudantes de medicina foi realizada em maio de 2020, utilizando questionários sobre status social e demográfico, o questionário GAD-7 para sintomas de ansiedade e o PHQ-9 para sintomas de depressão. Resultados: Um total de 340 de 347 (97,98\%) estudantes de medicina participou. A pontuação média do GAD-7 foi de 9,18 ( $( \pm 4,75)$, e a pontuação média do PHQ-9 foi de 12,72 $( \pm 6,62)$. Os resultados indicam uma relação positiva relevante entre o escore GAD-7 e sexo feminino ( $\mathrm{F}=5.816 \mathrm{P}=.016)$. Usando uma pontuação de corte de 10 para GAD-7, $157(46,17 \%)$ dos alunos foram identificados com sintomas de ansiedade moderados ou severos. Para a pontuação PHQ-9, utilizando-se um corte de 10 $219(64,41 \%)$ dos alunos foram reconhecidos com sintomas moderados ou severos de depressão; os resultados indicam uma relevante relação positiva entre o escore PHQ-9 e estudantes do sexo feminino $(\mathrm{F}=5.640 \mathrm{P}=.018)$. Conclusão: A análise demonstrou uma prevalência significativamente maior de sintomas moderados e severos de ansiedade e depressão entre estudantes de medicina do sexo feminino durante a Pandemia pelo COVID-19.
\end{abstract}

Palavras-chave: COVID-19; Saúde Mental; Estudante de Medicina; Ansiedade; Depressão.

\title{
Resumen
}

Antecedentes: los trastornos emocionales en los estudiantes de medicina son frecuentes y merecen especial atención durante la pandemia por COVID-19. Objetivo: Evaluar síntomas de trastornos de ansiedad y depresión en estudiantes de medicina durante la pandemia COVID-19. Métodos: Estudio transversal en una escuela de medicina privada en Brasil, dos meses después de la orden de permanencia en casa y clases en línea por la Pandemia por COVID-19. La encuesta entre estudiantes de medicina se realizó en mayo de 2020, utilizando cuestionarios sobre estado social y demográfico, el cuestionario GAD-7 para síntomas de ansiedad y PHQ-9 para síntomas de depresión. Resultados: participaron 340 de 347 (97,98\%) estudiantes de medicina. La puntuación media de GAD-7 fue de 9,18 ( $\pm 4,75)$ y la puntuación media de PHQ-9 fue de 12,72 $( \pm 6,62)$. Los resultados indican una relación positiva relevante entre el puntaje GAD-7 y el género femenino $(F=5,816 \mathrm{P}=.016)$. Utilizando una puntuación de corte de 10 para GAD-7, 157 $(46,17 \%)$ de los estudiantes fueron identificados con síntomas de ansiedad moderados o graves. Para la puntuación PHQ-9, utilizando un corte de $10219(64,41 \%)$ de los estudiantes, se les reconoció con síntomas moderados o graves de depresión; los resultados indican una relación positiva relevante entre el puntaje del PHQ-9 y 1 las estudiantes $(\mathrm{F}=$ $5,640 \mathrm{p}=.018)$. Conclusión: El análisis demostró una prevalencia significativamente mayor de síntomas moderados y severos de ansiedad y depresión entre las estudiantes de medicina durante la pandemia por COVID-19.

Palabras clave: COVID-19; Salud Mental; Estudiante de Medicina; Ansiedad; Depresión.

\section{Introduction}

The World Health Organization (WHO) declared the novel coronavirus disease 2019 (COVID-19) a pandemic, spreading rapidly and several risks of morbidity and mortality worldwide. (WHO, 2020) With prevention, many countries such as Brazil introduced restrictions including social distancing, self-isolation, and closure of social and educational institutions. Universities worldwide suspended or postponed all activities and substituted the classroom program for online classes. (Sahu, 2020) Medical schools face many challenges due to the COVID-19 Pandemic: shifting from classroom to online courses, impacting assessments and evaluation programs, travel restrictions among students from long distances, social limits, personal financial impairment due to pandemic period, and mental health impact. (Sahu, 2020) In medical undergraduates, emotional disorders are common and deserve special attention. (Ahmed, Banu, Al-Fageer, \& Al-Suwaidi, 2009; Lai et al., 2020; Moutinho et al., 2017; Pappa et al., 2020; Puthran, Zhang, Tam, \& Ho, 2016) Psychological reactions to pandemics, including maladaptive behaviors, emotional distress, and defensive responses, deserve special attention in this vulnerable group. (Cullen, Gulati, \& Kelly, 2020; Thomas \& Bendtsen, 2019) During this Pandemic period, there is a lack of knowledge for graduate students' mental health, especially in the medical area. This study aimed to evaluate the prevalence of anxiety and depression among medical students during the period of the COVID-19 Pandemic to identify groups that may require mental health care. The hypothesis that signs of anxiety and depression in medical students are higher during the COVID-19 Pandemic. Besides, anxiety and depression are higher among females and those who were not satisfied with online classes and those relating to economic status impairment. 


\section{Methodology}

A cross-sectional study including students from the medical school of Fundação Educacional do Município de Assis (FEMA), a private school located in the city of Assis, Sao Paulo state, Brazil, applied on May 18 and 19, 2020, two months after the stay-at-home authorities order and postponed classroom activities. We used the methodology from the ebook "Metodologia da Pesquisa Científica", proposed by Pereira, A. S. et al. (2018). The FEMA medical course completed, in 2020, the first five years of existence, whereas the medical graduation spans six years in Brazil. The inclusion criteria were all students more than 18 years old who were officially enrolled in the medical course. Students from FEMA medical school reside nationwide. At the time of the survey application, they were in social distancing and on stay-at-home recommendations since the FEMA council determined the postponed classroom activities on March 17 $7^{\text {th }}, 2020$. The Research Ethics Committee approved the Institution project under report number CAAE: 30718220.5.0000.8547, and all participants were invited to participate after informed consent. The parameters for calculating the sample were: confidence level of $95 \%$, the relative error of 5\%, and the unknown prevalence of the studied phenomena, which generates the most considerable variance. The result was 248 participants. The selfreported anonymous online survey form was sent via text message for each participant, containing informed consent, questionnaires about socio-demographics, educational evaluation, and anxiety and depression evaluation to all enrolled medical students of FEMA. Age, gender, questions about online education during the Pandemic, and questions about the financial status and its consequences about continuing enrollment in the course were applied.

We decided to categorize the age variable to preserve all participants' anonymity. The Generalized Anxiety Disorder (GAD-7) form, designed by Spitzer et al. (Spitzer, Kroenke, Williams, \& Löwe, 2006), is a seven-item self-report anxiety questionnaire applied. The items enquire about: the degree to which the patient has been bothered by feeling nervous or anxious, not being able to stop or control worrying, having trouble relaxing, worrying too much about different things, being so restless that it is hard to sit still, becoming easily annoyed and feeling afraid as if something might happen, in the last two weeks. We used a version of GAD-7 validated for the Portuguese language. (Sousa et al., 2015) We used a cut-off of 10, initially proposed by Kroenke et al. (Kroenke, Spitzer, Williams, Monahan, \& Löwe, 2007), with a sensitivity of $89 \%$ and specificity of $82 \%$ for GAD.

The Patient Health Questionnaire (PHQ) uses scores of the depression criteria classified as "0" (not at all) to "3" (nearly every day). At nine items, the PHQ depression scale has comparable sensitivity and specificity to other length questionnaires and consists of the essential nine criteria upon which the diagnosis of DSM-IV depressive disorders is based. (Kroenke, Spitzer, \& Williams, 2001b) A validated Portuguese version of the PHQ-9 was applied. (Santos et al., 2013) We attempted to determine a cut-off of 10 for screening depressive disorder, following the meta-analysis results from Manea et al. (Manea, Gilbody, \& McMillan, 2012), which reported no significant differences in pooled sensitivity and specificity for cut-off scores between 8 and 11. A cut-off of 10 is consistent with the initial validation study from Kroenke et al., which had a sensitivity of $88 \%$ and a specificity of $88 \%$ for detecting major depressive disorders. (Kroenke, Spitzer, \& Williams, 2001a)

We analyzed the data with SPSS software (IBM Corp., Armonk, NY). Continuous data are expressed as the mean (M) and standard deviation (S.D.). An independent sample t-test was conducted to determine whether there is a difference in the GAD-7 score for anxiety and the PHQ-9 score for depression between males and females. One-way ANOVA was conducted to assess the effect of age on scores. A Pearson correlation coefficient was computed to determine the relationship between the GAD-7 score, PHQ-9 score, age, gender, and financial status during the social isolation period. We adopted a P-value of <.05 and a confidence interval of $95 \%$. 


\section{Results and Discussion}

Of the 347 medical students enrolled, 340 (97.98\%) answered the survey: 89 male medical students (26.20\%) and 251 female medical students (73.80\%) (Table 1). One hundred ten medical students were 18-20 years old (32.40\%), 216 were 21-29 years old (63.50\%), and 14 were 30 years old or older (4.10\%) and declared single status 317 (93.20\%). Five students reported prior suspecting or confirmation of COVID-19 infection (1.47\%), 281 (83.14\%) students agreed with the stay-at-home order from public health authorities, and 196 (57.82\%) declared total or nearly total isolation at home. Declared afraid of becoming infected by COVID-19, 288 (84.71\%) students. Concerning online classes during the Pandemic and social distancing, 194 of 340 participants $(57.06 \%)$ declared satisfied. When questioned about income knowledge due to online courses, 294 of 340 medical students $(86.73 \%)$ referred to less than presential classes. When asked about the continuation of postponed educational activities at the campus, 147 of 340 (43.24\%) preferred to continue the online education, 120 of 340 (35.29\%) favored suspending the course, and 73 of 340 (21.47\%) were in doubt about continuing or not continuing the course in this situation. A total of 240 of $340(70.80 \%)$ students referred impairment in their financial status that may compromise their continuity on the course, and 99 of $340(29.20 \%)$ students responded that social isolation due to the Pandemic has not affected their financial status and therefore not affected their continuity on the course.

Table 1. Frequencies for Age, Gender, Marital status, COVID-19, Online classes, and Financial impairment affecting graduating

\begin{tabular}{lll}
\hline Variable & $\mathrm{N}$ & $\%$ \\
\cline { 2 - 3 } Age & & \\
$18-20$ & 110 & 32.40 \\
$21-29$ & 216 & 63.50 \\
30 and older & 14 & 4.10 \\
Gender & & \\
Male & 89 & 26.20 \\
Female & 251 & 73.80 \\
Marital status & & \\
Single & 317 & 93.20 \\
No single & 33 & 6.80 \\
Prior COVID infection or suspected & 05 & 1.47 \\
Social distancing agreement & 196 & 57.82 \\
Afraid of being COVID-19 infection & 288 & 84.71 \\
Satisfaction about online classes & 194 & 57.06 \\
Referred less income knowledge with online classes & 294 & 86.73 \\
Online classes should continue whether stay-at-home status persists & 147 & 43.24 \\
Social distancing and financial impairment may affect their graduation & 240 & 70.80 \\
\hline
\end{tabular}

$\mathrm{N}=340$.

Source: Authors.

The average GAD-7 score for anxiety was $9.18( \pm 4.75)$, and the average PHQ-9 score for depression was $12.72( \pm 6.62)$ (Table 2). Using a cut-off score of 10 for GAD-7, we found 157 of 340 (46.17\%) medical students with moderated or severe symptoms of GAD. For the PHQ-9 score, using a cut-off of 10, 219 of 340 (64.41\%) medical students reported moderate or severe symptoms of depression. 
Table 2. Descriptive Statistics for GAD-7 score for anxiety and PHQ-9 score for depression (N=340).

\begin{tabular}{lr}
\hline Variable & Mean (SD) \\
\hline GAD-7 score for anxiety & $9.18(4.75)$ \\
PHQ-9 score for depression & $12.72(6.62)$ \\
\hline
\end{tabular}

Source: Authors.

An independent sample t-test (Table 3) was conducted to determine whether there is a difference in the GAD-7 score for anxiety between males and females. The results indicate a significant difference between males $($ Mean $8.15 \pm 4.41)$ and females (Mean $9.55 \pm 4.82)$; ( $(338)=-2.41 ; P=.015)$. The 95\% confidence interval of the difference between means ranged from (-2.55 to -0.26). An independent sample t-test was conducted to determine whether there is a difference in the PHQ-9 score for depression between males and females. The results indicate a significant difference between males (Mean 11.29 \pm 6.37$)$ and females (Mean $13.22 \pm 6.65)$; ( $(338)=-2.38 ; \mathrm{P}=.018)$. The 95\% confidence interval of the difference between means ranged from $(-3.52$ to -0.33$)$.

Table 3. Independent samples t-test results for gender and GAD-7 and PHQ-9 score.

\begin{tabular}{|c|c|c|c|c|c|c|c|}
\hline \multirow[b]{3}{*}{ Variable } & \multicolumn{4}{|c|}{ Gender } & \multirow[b]{3}{*}{$\mathrm{T}$} & \multirow[b]{3}{*}{$P$} & \multirow[b]{3}{*}{$95 \% \mathrm{CI}$} \\
\hline & \multicolumn{2}{|c|}{$\begin{array}{c}\text { Male } \\
(n=89)\end{array}$} & \multicolumn{2}{|c|}{$\begin{array}{c}\text { Female } \\
(n=251)\end{array}$} & & & \\
\hline & Mean & (SD) & Mean & & & & \\
\hline GAD-7 score & 8.15 & $( \pm 4.41)$ & 9.55 & $( \pm 4.82)$ & -2.41 & .016 & $(-2.55$ to -0.26$)$ \\
\hline PHQ-9 score & 11.29 & $( \pm 6.37)$ & 13.22 & $( \pm 6.65)$ & -2.38 & .018 & $(-3.52$ to -0.33$)$ \\
\hline
\end{tabular}

One-way ANOVA (Table 4) was conducted to determine the effect of age $(18-20 ; 21-29 ; \geq 30)$ on the GAD-7 score for anxiety. The results indicate a non-significant effect, $\mathrm{F}(2,337)=1.07, P=.345$. One-way ANOVA was conducted to determine the effect of age $(18-20 ; 21-29 ; \geq 30)$ on the PHQ-9 score for depression. The results indicate a non-significant effect, F (2, 337) $=0.47, P=.623$.

Table 4. One-way ANOVA results.

\begin{tabular}{|c|c|c|c|c|c|c|c|c|}
\hline \multirow[b]{3}{*}{ Variable } & \multicolumn{6}{|c|}{ Age } & \multirow[b]{3}{*}{$\mathrm{F}$} & \multirow[b]{3}{*}{$P$} \\
\hline & \multicolumn{2}{|c|}{$\begin{array}{c}18-20 \\
(n=110)\end{array}$} & \multicolumn{2}{|c|}{$\begin{array}{c}21-29 \\
(\mathrm{n}=216)\end{array}$} & \multicolumn{2}{|c|}{$\begin{array}{c}>=30 \\
(n=14)\end{array}$} & & \\
\hline & Mean & (SD) & Mean & (SD) & Mean & (SD) & & \\
\hline GAD-7 score & 9.58 & $(5.10)$ & 8.91 & $(4.64)$ & 10.21 & (3.24) & 1.07 & .345 \\
\hline PHQ-9 score & 12.96 & (7.04) & 12.51 & (6.39) & 14.07 & $(6.97)$ & 0.47 & .623 \\
\hline
\end{tabular}

$\mathrm{P}<.05$

$\mathrm{N}=340$

Source: Authors.

The Pearson correlation coefficient (Table 5) was conducted to determine the relationship between GAD-7 total score and age, GAD-7 total score and female, GAD-7 total score, and "social distancing does not affect the financial status and does not affect continuity on course"; GAD-7 total score and "social distancing will affect my financial status and my continuity on course"; GAD-7 total score and "social distancing may partially affect my financial status and continuity on the course." 
Table 5. Correlations between GAD-7 total score, age, gender, and financial status.

\begin{tabular}{|c|c|c|c|c|c|c|c|c|c|}
\hline & & & $\begin{array}{c}\text { Age } \\
18-20\end{array}$ & $\begin{array}{c}\text { Age } \\
21-29\end{array}$ & $\begin{array}{l}\text { Age } \\
\geq 30\end{array}$ & Female & $\dagger$ & $\ddagger$ & $\S$ \\
\hline GAD-7 & $\mathrm{R}$ & 1 & .058 & -.075 & .045 & $.130^{\mathrm{a}}$ & $-.114^{\mathrm{a}}$ & $.150^{\mathrm{b}}$ & -.002 \\
\hline total score & $P$ & & .284 & .167 & .407 & .016 & .036 & .005 & .972 \\
\hline \multirow[t]{2}{*}{ Age $18-20$} & $\mathrm{R}$ & .058 & 1 & $-.913^{\mathrm{b}}$ & $-.143^{b}$ & $.126^{\mathrm{a}}$ & .058 & -.101 & .038 \\
\hline & $P$ & .284 & & .000 & .008 & .020 & .288 & .063 & .484 \\
\hline \multirow[t]{2}{*}{ Age $21-29$} & $\mathrm{R}$ & -.075 & $-.913^{b}$ & 1 & $-.274^{\mathrm{b}}$ & $-.118^{\mathrm{a}}$ & -.028 & .063 & -.036 \\
\hline & $P$ & .167 & .000 & & .000 & .030 & .607 & .248 & .514 \\
\hline \multirow[t]{2}{*}{ Age $\geq 30$} & $\mathrm{R}$ & .045 & $-.143^{b}$ & $-.274^{\mathrm{b}}$ & 1 & -.011 & -.068 & .085 & -.004 \\
\hline & $P$ & .407 & .008 & .000 & & .836 & .211 & .116 & .946 \\
\hline \multirow[t]{2}{*}{ Female } & $\mathrm{R}$ & $.130^{\mathrm{a}}$ & $.126^{\mathrm{a}}$ & $-.118^{\mathrm{a}}$ & -.011 & 1 & .044 & $\begin{array}{l}.029 \\
\end{array}$ & .004 \\
\hline & $P$ & .016 & .020 & .030 & .836 & & .418 & .592 & .944 \\
\hline
\end{tabular}

$\uparrow$ Social distancing due to the Pandemic does not affect the financial status and does not affect the course's continuity.

$\$$ Social distancing due to the Pandemic affects the financial status and influences the course's continuity.

$\S$ Social distancing due to the Pandemic may partially affect the financial status and influence the course's continuity.

${ }^{\text {a }}$ Correlation is significant at the 0.05 level (2-tailed).

${ }^{\mathrm{b}}$ Correlation is significant at the 0.01 level (2-tailed).

$P<.05$

$\mathrm{N}=340$

Source: Authors.

The results indicate a positive nonsignificant relationship between GAD-7 total score and age 18-20; r $(340)=0.058$, $P=.284$. A negative non-significant relationship between GAD-7 total score and age $21-29 ; \mathrm{r}(340)=-0.075, P=.167$. A positive nonsignificant relationship between GAD-7 total score and age 30 and over; $\mathrm{r}(340)=0.045, P=.407$. There was a significant positive relationship between the GAD-7 total score and the female gender (r $(340)=0.130, P=.016)$. A significant negative relationship between GAD-7 total score and "social distancing due to the Pandemic does not affect my financial status." Does not affect continuity on course; $\mathrm{r}(339)=-0.114, P=.036$. A significant positive relationship between GAD-7 total score and social distancing due to the Pandemic will affect my financial status and my course continuity; r $(340)=0.150, P=.005$. A negative nonsignificant relationship between GAD-7 total score and social distancing due to the Pandemic may partially affect my financial status and continuity on the course; $r(340)=-0.002 P=.972$.

The Pearson correlation coefficient was computed to determine the relationship between PHQ-9 total score and age 1820; PHQ-9 total score and age 21-29; PHQ-9 total score and 30 years and over; PHQ-9 total score and female; PHQ-9 total score and social distancing due to the Pandemic does not affect financial status. "Does not affect continuing enrollment in the course," PHQ-9 total score and "social distancing due to the Pandemic will affect the financial status and continuing enrollment in the course"; PHQ-9 total score and "social distancing due to the Pandemic may partially affect my financial status and continuity in the course" (Table 6). 
Table 6. Correlations between PHQ-9 total score, age, gender, and financial status.

\begin{tabular}{lccccccccc}
\hline & & & Age & Age & Age & & & \\
& & & $18-20$ & $21-29$ & $\geq 30$ & Female & $\dagger$ & $\dagger$ & $\S$ \\
\hline PHQ-9 total score & $\mathrm{R}$ & 1 & .025 & -.042 & .043 & $.128^{\mathrm{a}}$ & -.077 & $.162^{\mathrm{b}}$ & -.050 \\
& $P$ & & .645 & .441 & .434 & .018 & .155 & .003 & .354 \\
\cline { 2 - 10 } Age & $\mathrm{R}$ & .025 & 1 & $-.913^{\mathrm{b}}$ & $-.143^{\mathrm{b}}$ & $.126^{\mathrm{a}}$ & .058 & -.101 & .038 \\
$18-20$ & $P$ & .645 & & .000 & .008 & .020 & .288 & .063 & .484 \\
Age 21-29 & $\mathrm{R}$ & -.042 & $-.913^{\mathrm{b}}$ & 1 & $-.274^{\mathrm{b}}$ & $-.118^{\mathrm{a}}$ & -.028 & .063 & -.036 \\
& $P$ & .441 & .000 & & .000 & .030 & .607 & .248 & .514 \\
\cline { 2 - 10 } Age $\geq 30$ & $\mathrm{R}$ & .043 & $-.143^{\mathrm{b}}$ & $-.274^{\mathrm{b}}$ & 1 & -.011 & -.068 & .085 & -.004 \\
& $P$ & .434 & .008 & .000 & & .836 & .211 & .116 & .946 \\
Female & $\mathrm{R}$ & $.128^{\mathrm{a}}$ & $.126^{\mathrm{a}}$ & $-.118^{\mathrm{a}}$ & -.011 & 1 & .044 & -.029 & .004 \\
& $P$ & .018 & .020 & .030 & .836 & & .418 & .592 & .944 \\
\hline
\end{tabular}

$†$ Social distancing due to the Pandemic does not affect the financial status and does not affect the course's continuity.

\$ Social distancing due to the Pandemic affects the financial status and the continuity of the course.

$\S$ Social distancing due to the Pandemic may partially affect the financial status and the continuity of the course.

${ }^{\text {a }}$ Correlation is significant at the 0.05 level (2-tailed).

${ }^{\mathrm{b}}$ Correlation is significant at the 0.01 level (2-tailed).

$\mathrm{P}<.05$

$\mathrm{N}=340$

Source: Authors.

The results indicate a positive nonsignificant relationship between PHQ-9 total score and age 18-20; r (340) =0.025, $=.645$. A negative nonsignificant relationship between PHQ-9 total score and age 21-29; r $(340)=-0.042, P=.441$. A positive nonsignificant relationship between PHQ-9 total score and age 30 and over; $\mathrm{r}(340)=0.043, P=.434$. There was a significant positive relationship between PHQ-9 total score and female sex $(\mathrm{r}(340)=0.128, P=.018)$. A negative nonsignificant relationship between PHQ-9 total score and the social distancing due to the Pandemic does not affect financial status. Does not affect continuing enrollment in the course; $\mathrm{r}(339)=-0.077, P=.155$. A significant positive relationship between PHQ-9 total score and social distancing due to the Pandemic will affect the financial status and continuing enrollment in the course; $r(340)=0.162$, $P=.003$. A negative nonsignificant relationship between PHQ-9 total score and social distancing due to the Pandemic may partially affect the financial status and continuity of being enrolled in the course; $r(340)=-0.050$. $P=.354$.

We demonstrated that 157 of $340(46.17 \%)$ medical students scored ten or more as having moderate or severe anxiety symptoms in the GAD-7 questionnaire, and 219 of $340(64,41 \%)$ scored as having moderate or severe symptoms of depression.

Before the Pandemic, another study conducted in Brazil showed 38.2\% of symptoms of depression among medical students. (Baldassin, Alves, De Andrade, \& Nogueira Martins, 2008) In 2017, before the Pandemic, Moutinho et al. reported $34.6 \%$ depressive symptoms and 37.2\% anxiety symptoms in Brazilian medical students. (Moutinho et al., 2017) Puthran et al. in 2016 (Puthran et al., 2016) published a meta-analysis finding for a total of 62728 medical students across 77 studies, a global prevalence of depression among medical students of $28.0 \%$ (95\% CI 24.2-32.1). In that meta-analysis, women were more likely to be depressed, but not significantly. Our results revealed a higher prevalence of anxiety and depression among medical students, with a relevant higher prevalence in females and students with alleged financial status impairment. Studies have demonstrated 
that women have a higher prevalence of anxiety and depression among the general population and medical students. (Dyrbye, Thomas, \& Shanafelt, 2006; Moutinho et al., 2017) In India, Iqbal et al. reported higher scores of depression, anxiety, and stress associated with the female gender, the lower semester, younger age, and non-smokers. (Iqbal, Gupta, \& Venkatarao, 2015)

We used a type of methodology that has been applied in several other studies on medical schools. Furthermore, the GAD-7 and PHQ-9 are well-known methods of assessing anxiety and depression symptoms, respectively. Different strengths were the massive and representative participation of students (97.98\%), responding to the text message in only two days, revealing compliance with this evaluation. The relevance of studying mental health during the COVID-19 outbreak has been recognized, especially in a population of medical students known to be more vulnerable to depression, anxiety, and other stressrelated conditions. (Rosenthal \& Okie, 2005)

Limitations: First, we cannot explain the heterogeneity between other studies, and caution should be taken when interpreting the results. Although the psychometric properties of the GAD-7 were strong, the measure may better serve as an indicator of GAD severity than a screening tool for the presence or absence of GAD. (Rosenthal \& Okie, 2005) Future studies should investigate the convergent and discriminant validity of the GAD-7 concerning other criteria (e.g., behavioral, biological, information-processing) relevant to the psychopathology of GAD. (Beard \& Björgvinsson, 2014) The second limitation is that the PHQ-9 is valid only for screening purposes for "current major depressive episode" due to its low positive predictive value. (Inoue et al., 2012)

Third, we had only 14 students 30 years old or older, which is a possible limitation concerning age sampling. Furthermore, we do not consider another variable analysis, such as marital status, race, and employment status. According to the FEMA academic registry, the majority enrolled were single, Caucasian, not a worker, and financially dependent. Another limitation is that we do not have baseline data about mental health disorders regarding medical students with FEMA before the COVID-19 Pandemic to be compared. Besides, it is well known that in cross-sectional studies, data are assessed at the same time, and no evidence of a temporal relationship is achieved between exposure and outcomes. We used not validated criteria assessment. Thus, it is necessarily better to understand each participant's social distancing and financial status, and in our concern, this may be a bias when comparing the results from other cohorts. We did not consider the year of graduation as a variable because our Institution has completed only four years of the medical course at this time. This study was conducted in only one medical college in Brazil; although our medical students reside nationwide, this situation impacts the generalizability of the findings.

\section{Conclusion}

Our analyses demonstrated a higher prevalence of moderate and severe anxiety and depression symptoms among medical students during the COVID-19 Pandemic. Furthermore, the results were significantly higher among females. Interventions regarding mental health in undergraduate medical students, especially in times of the COVID-19 Pandemic, where a stressful environment harms academic performance, physical health, psychosocial wellbeing, and financial status, are demanded and imperative. Automated mobile phone format and text messaging during the pandemic social distancing period are recognized and suggested tools to enhance positive mental health among college students. (Bendtsen, Müssener, Linderoth, \& Thomas, 2020; Thomas \& Bendtsen, 2019) Current findings suggest that medical schools and health authorities should offer prevention, early detection, and interventions for mental health disorders in undergraduate medical students. Further studies are mandatory to analyze and propose interventions to mitigate mental health disorders due to COVID-19 Pandemic. 


\section{Acknowledgments}

We dedicate this study to all educators and medical students from the Faculty of Medicine of FEMA.

\section{References}

Ahmed, I., Banu, H., Al-Fageer, R., \& Al-Suwaidi, R. (2009). Cognitive emotions: Depression and anxiety in medical students and staff. Journal of Critical Care, 24(3), e1-e7. https://doi.org/10.1016/j.jcrc.2009.06.003

Baldassin, S., Alves, T. C. D. T. F., De Andrade, A. G., \& Nogueira Martins, L. A. (2008). The characteristics of depressive symptoms in medical students during medical education and training: A cross-sectional study. BMC Medical Education. https://doi.org/10.1186/1472-6920-8-60

Beard, C., \& Björgvinsson, T. (2014). Beyond generalized anxiety disorder: Psychometric properties of the GAD-7 in a heterogeneous psychiatric sample. Journal of Anxiety Disorders. https://doi.org/10.1016/j.janxdis.2014.06.002

Bendtsen, M., Müssener, U., Linderoth, C., \& Thomas, K. (2020). A Mobile Health Intervention for Mental Health Promotion Among University Students: Randomized Controlled Trial. JMIR MHealth and UHealth, 8(3), e17208. https://doi.org/10.2196/17208

Cullen, W., Gulati, G., \& Kelly, B. D. (2020). Mental health in the COVID-19 Pandemic. QJM: An International Journal of Medicine, 113(5), 311-312. https://doi.org/10.1093/qjmed/hcaa110

Dyrbye, L. N., Thomas, M. R., \& Shanafelt, T. D. (2006). Systematic review of depression, anxiety, and other indicators of psychological distress among U.S. and Canadian medical students. Academic Medicine, 81(4), 354-373. https://doi.org/10.1097/00001888-200604000-00009

Inoue, T., Tanaka, T., Nakagawa, S., Nakato, Y., Kameyama, R., Boku, S., .. Koyama, T. (2012). Utility and limitations of PHQ-9 in a clinic specializing in psychiatric care. BMC Psychiatry. https://doi.org/10.1186/1471-244X-12-73

Iqbal, S., Gupta, S., \& Venkatarao, E. (2015). Stress, anxiety \& depression among medical undergraduate students \& their socio-demographic correlates. Indian Journal of Medical Research, Supplement, 141(Mar2015), 354-357. https://doi.org/10.4103/0971-5916.156571

Kroenke, K., Spitzer, R. L., \& Williams, J. B. W. (2001a). The PHQ-9: Validity of a brief depression severity measure. Journal of General Internal Medicine. https://doi.org/10.1046/j.1525-1497.2001.016009606.x

Kroenke, K., Spitzer, R. L., \& Williams, J. B. W. (2001b). The PHQ-9. Journal of General Internal Medicine, 16(9), 606-613. https://doi.org/10.1046/j.15251497.2001.016009606.x

Kroenke, K., Spitzer, R. L., Williams, J. B. W., Monahan, P. O., \& Löwe, B. (2007). Anxiety disorders in primary care: Prevalence, impairment, comorbidity, and detection. Annals of Internal Medicine, 146(5), 317-325. https://doi.org/10.7326/0003-4819-146-5-200703060-00004

Lai, J., Ma, S., Wang, Y., Cai, Z., Hu, J., Wei, N., \& Hu, S. (2020). Factors Associated With Mental Health Outcomes Among Health Care Workers Exposed to Coronavirus Disease 2019. JAMA Network Open, 3(3), e203976. https://doi.org/10.1001/jamanetworkopen.2020.3976

Manea, L., Gilbody, S., \& McMillan, D. (2012). Optimal cut-off score for diagnosing depression with the Patient Health Questionnaire (PHQ-9): a meta-analysis. Canadian Medical Association Journal, 184(3), E191-E196. https://doi.org/10.1503/cmaj.110829

Moutinho, I. L. D., Maddalena, N. de C. P., Roland, R. K., Lucchetti, A. L. G., Tibiriçá, S. H. C., Ezequiel, O. da S., \& Lucchetti, G. (2017). Depression, stress and anxiety in medical students: A cross-sectional comparison between students from different semesters. Revista Da Associação Médica Brasileira, 63(1), 2128. https://doi.org/10.1590/1806-9282.63.01.21

Pappa, S., Ntella, V., Giannakas, T., Giannakoulis, V. G., Papoutsi, E., \& Katsaounou, P. (2020). Prevalence of depression, anxiety, and insomnia among healthcare workers during the COVID-19 Pandemic: A systematic review and meta-analysis. Brain, Behavior, and Immunity, https://doi.org/10.1016/j.bbi.2020.05.026

Puthran, R., Zhang, M. W. B., Tam, W. W., \& Ho, R. C. (2016). Prevalence of depression amongst medical students: a meta-analysis. Medical Education, 50(4), 456-468. https://doi.org/10.1111/medu.12962

Rosenthal, J. M., \& Okie, S. (2005). White Coat, Mood Indigo - Depression in Medical School. New England Journal of Medicine, 353(11), 1085-1088. https://doi.org/10.1056/NEJMp058183

Sahu, P. (2020). Closure of Universities Due to Coronavirus Disease 2019 (COVID-19): Impact on Education and Mental Health of Students and Academic Staff. Cureus, 2019(4), 4-9. https://doi.org/10.7759/cureus.7541

Santos, I. S., Tavares, B. F., Munhoz, T. N., Almeida, L. S. P. de, Silva, N. T. B. da, Tams, B. D., \& Matijasevich, A. (2013). Sensibilidade e especificidade do Patient Health Questionnaire-9 (PHQ-9) entre adultos da população geral. Cadernos de Saúde Pública, 29(8), 1533-1543. https://doi.org/10.1590/0102$311 \times 00144612$

Sousa, T. V., Viveiros, V., Chai, M. V., Vicente, F. L., Jesus, G., Carnot, M. J., ... Ferreira, P. L. (2015). Reliability and validity of the Portuguese version of the Generalized Anxiety Disorder (GAD-7) scale. Health and Quality of Life Outcomes. https://doi.org/10.1186/s12955-015-0244-2

Spitzer, R. L., Kroenke, K., Williams, J. B. W., \& Löwe, B. (2006). A brief measure for assessing generalized anxiety disorder: The GAD-7. Archives of Internal Medicine. https://doi.org/10.1001/archinte.166.10.1092

Thomas, K., \& Bendtsen, M. (2019). Mental Health Promotion Among University Students Using Text Messaging: Protocol for a Randomized Controlled Trial of a Mobile Phone-Based Intervention. JMIR Research Protocols, 8(8), e12396. https://doi.org/10.2196/12396

WHO. (2020). WHO Characterizes COVID-19 as A Pandemic. World Health Organization. Retrieved from https://www.who.int/emergencies/diseases/novelcoronavirus-2019 